\title{
The Protective Effect of Taxifolin Against Amikacin-induced Ototoxicity in Rats: a Biochemical and Histopathological Evaluation
}

\author{
Taxifolinin Sıçanlarda Amikasin ile Indüklenen Ototoksisiteye Karșı Koruyucu Etkisi: \\ Biyokimyasal ve Histopatolojik Değerlendirme
}

\author{
Ertugrul Erhan' ${ }^{1}$ Ismail Salcan ${ }^{2}$, Muhammet Dilber ${ }^{3}$, Cebrail Gursul $^{4}$, Sevil Karahan Yilmaz ${ }^{5}$, \\ Taha Abdulkadir Coban ${ }^{6}$, Ferda Keskin Cimen ${ }^{7}$, Halis Suleyman ${ }^{8}$
}

${ }^{1}$ Department of Otorhinolaryngology, Erzincan Binali Yildirim University Faculty of Medicine, Erzincan, Turkey; ${ }^{2}$ Department of Otorbinolaryngology, Mengücek Gazi Training and Research Hospital, Erzincan, Turkey; ${ }^{3}$ Dilber ENT \& Aesthetic Clinic, Istanbul, Turkey; ${ }^{4}$ Department of Physiology, Erzincan Binali Yildirim University Faculty of Medicine, Erzincan, Turkey; Department of Nutrition and Dietetics, Faculty of Health Sciences, Erzincan Binali Yildirim University, Erzincan, Turkey; ${ }^{6}$ Department of Biochemistry, Erzincan Binali Yildirim University Faculty of Medicine, Erzincan, Turkey; ${ }^{7}$ Department of Medical Pathology, Erzincan Binali Yildirim University Faculty of Medicine, Erzincan, Turkey; ${ }^{8}$ Department of Pharmacology, Erzincan Binali Yildirim University Faculty of Medicine, Erzincan, Turkey

\begin{abstract}
Aim: Amikacin is a semi-synthetic aminoglycoside derivative antibacterial drug. Amikacin's cochleotoxic effects causing permanent hearing loss have been reported. Over-production of reactive oxygen species (ROS) are responsible for the ototoxicity of amikacin. The study investigates the protective effect of Taxifolin (3.5.7.3.4-pentahydroxy flavanone), an antioxidant flavonoid, against amikacin-induced ototoxicity. The objective is to biochemically and histopathologically investigate the protective effect of taxifolin against amikacin-induced ototoxicity in male albino Wistar rats.

Material and Method: TAK group animals were administered taxifolin $50 \mathrm{mg} / \mathrm{kg}(\mathrm{n}-6)$ by oral gavage. AMK (n-6) and HG (n-6) groups were administered distilled water as solvent using the same method. One hour after taxifolin and distilled water administration, TAK and AMK groups were given $200 \mathrm{mg} / \mathrm{kg}$ amikacin by intramuscular route. This procedure was performed once a day for 14 days. Cochlear tissues extracted from the animals killed after this period with high doses of ketamine $(120 \mathrm{mg} / \mathrm{kg})$ were investigated biochemically and histopathologically.
\end{abstract}

Results: Histopathological damage such as edema and deconstruction was observed in cochlear tissues of the AMK group where malondialdehyde (MDA) and total oxidant status (TOS) were high and total glutathione (tGSH) and total antioxidant status (TAS) were low. However, no histopathological finding except for mild edema was observed in the TAK group where MDA, TOS, $t G S H$, and TAS levels were close to those of the HG group.

Conclusion: Taxifolin may be beneficial in terms of preventing amikacin-induced cochlear damage.

Key words: amikacin; taxifolin; ototoxicity; rat

\section{ÖZET}

Amaç: Amikasin, yarı sentetik aminoglikozid türevi antibakteriyel bir ilaçtır. Amikasinin kalıcı ișitme kaybına yol açan kokleotoksik etkileri rapor edilmiștir. Amikasin ototoksisitesinden, reaktif oksijen türlerinin (ROS) așırı üretimi sorumlu tutulmaktadır. Çalıșmamızda amikasin ile indüklenen ototoksisiteye karșı koruyucu etkisini araștıracağımı Taxifolin (3.5.7,3,4-pentahydroxy flavanone) antioksidan bir flavonoiddir. Taxifolinin albino Wistar türü erkek sıçanlarda amikasin ile indüklenen ototoksisiteye karșı koruyucu etkisini biyokimyasal ve histopatolojik olarak araștırmak amaçlanmaktadır.

Materyal ve Metot: Hayvanların TAK grubuna taxifolin $50 \mathrm{mg} / \mathrm{kg}$ (n-6) oral yoldan gavajla verildi. AMK (n-6) ve HG (n-6) gruplarına ise çözücü olarak distile su aynı hacimde aynı yöntemle uygulandı. Taxifolin ve distile su verildikten bir saat sonra TAK ve AMK gruplarına amikasin 200 mg/kg intramusküler yoldan enjekte edildi. Bu prosedür günde bir defa 14 gün boyunca uygulandı. Bu süre sonunda yüksek doz ketamile (120 mg/kg) öldürülen hayvanlardan çıkarılan koklea dokuları biyokimyasal ve histopatolojik olarak incelendi.

Bulgular: Malondialdehid (MDA) ve total oksidan statusun (TOS) yüksek, total glutatyon (tGSH) ve total antioksidan statüsun (TAS) düșük bulunduğu AMK grubunun koklea dokusunda ödem ve destrüksiyon gibi histopatolojik hasar görülmüștür. Ancak, MDA, TOS, tGSH ve TAS düzeyleri HG grubuna yakın olan TAK grubunda hafif ödem dıșında herhangi bir histopatolojik bulgulara rastlanmadı.

Sonuç: Taksifolin, amikasinle ilișkili koklea hasarının önlenmesinde yararlı olabileceğini ișaret etmektedir.

Anahtar kelimeler: amikasin; taksifolin; ototoksitite; rat

IIetișim/Contact: Halis Süleyman, Erzincan Binali Yildirim University Faculty of Medicine, Department of Pharmacology, Erzincan, Turkey • Tel:044622618 18,0530921 1909 • E-mail: halis.suleyman@gmail.com • Geliș/Received:07.12.2020 • Kabul/Accepted:08.02.2021

ORCID: Ertuğrul Erhan, 0000-0002-7172-0174 • Ismail Salcan, 0000-0001-8034-1064 • Muhammet Dilber, 0000-0001-5835-3181 • Cebrail Gürsul, 0000-0001-6521-6169 • Sevil Karahan Ylmaz, 0000-0002-7446-4508 • Taha Abdulkadir Coban, 0000-0003-1711-5499 • Ferda Keskin Cimen, 0000-0002-1844-0827 • Halis Süleyman, 0000-0002-9239-4099 


\section{Introduction}

Amikacin is a semi-synthetic aminoglycoside derivative antibacterial drug obtained by acetylation of kanamycin ${ }^{1}$. Amikacin is resistant to bacterial enzymes that can inactivate other natural aminoglycosides ${ }^{2}$. Aminoglycoside antibiotics (AGAs) are known for their rapid activity, low bacterial resistance, synergistic activity with beta lactams and their low cost ${ }^{3}$. Although AGAs include a wide range and have numerous areas of application, their adverse effects limit their use ${ }^{4}$. According to various studies, the ototoxicity incidence of AGAs range between $10 \%$ and $80 \%{ }^{5}$. Similar to other AGAs, amikacin also has cochleotoxic effects causing permanent hearing loss 4 . Ototoxicity is a clinical condition caused usually by the harmful effects of some chemical agents on hearing and balancing functions of the ear ${ }^{6}$. Over-production of reactive oxygen species (ROS) is held responsible for the pathogenesis of amikacin ototoxicity ${ }^{7,8}$. Aksoy F. et al. ${ }^{9}$ reported that there were many experimental studies demonstrating that antioxidant agents can prevent AGA ototoxicity.

The present study investigate the protective effect of Taxifolin (3.5.7.3.4-pentahydroxy flavanone or dihydroquercetine), against amikacin-induced ototoxicity. Taxifolin is an antioxidant flavonoid that can be found in citrus and onion in high quantities ${ }^{10}$. In literature, flavonoids have been reported to inhibit lipid peroxidation and enzymatic reactions that produce $\mathrm{ROS}^{11}$. Taxifolin has been reported to protect tissues from oxidative damage by inhibiting malondialdehyde (MDA) increase in various organ tissues and glutathione $(\mathrm{GSH})$ decrease, which is an endogenous antioxidant ${ }^{12-14}$. Taxifolin use is also recommended to minimize lipid oxidation in food and pharmaceutical products ${ }^{15}$. All this information demonstrate that ROS is a major component in the pathogenesis of amikacin-induced ototoxicity. It is believed that taxifolin can be beneficial in treating amikacin-induced ototoxicity damage. There was no information in the literature about the protective effect of taxifolin against amikacin-induced ototoxicity. For this reason, the objective of our study is to biochemically and histopathologically investigate the protective effect of taxifolin against amikacin-induced ototoxicity in male albino Wistar rats.

\section{Material and Methods}

\section{Animals}

Male albino Wistar rats to be used in the study were obtained from the Medical Experimental Research and
Application Center of Ataturk University. A total of 18 male albino Wistar rats weighing between 290 and 305 grams were used for the experiment. Prior to the experiment, animals were housed and fed in groups at normal room temperature $\left(22^{\circ} \mathrm{C}\right)$.

\section{Chemicals}

Ketamine used in the experiment was supplied from Pfizer Ilaçlari Ltd. Şti. (Turkey), amikacin from Sanofi Ilaç San. (Turkey) and taxifolin from Evalar-Russia.

\section{Animal Groups}

Experimental animals were divided into three groups: amikacin (AMK) administered, taxifolin+amikacin administered and the control group (HG).

\section{Experimental Procedure}

Pharmacological procedure: TAK group animals were administered taxifolin $50 \mathrm{mg} / \mathrm{kg}(\mathrm{n}-6)$ by oral gavage. AMK (n-6) and HG (n-6) groups were administered distilled water as solvent using the same method. One hour after taxifolin and distilled water administration, TAK and AMK groups were given $200 \mathrm{mg} / \mathrm{kg}$ amikacin by intramuscular route. This procedure was performed once a day for 14 days. Cochlear tissues extracted from the animals killed after this period with high doses of ketamine $(120 \mathrm{mg} / \mathrm{kg})$ were investigated biochemically and histopathologically. Biochemical and histopathological examinations were performed on removed cochlear tissues. Biochemical and histopathological results obtained from TAK and HG animal groups were compared with those of the AMK group.

Biochemical analyses: Homogenates of cochlear tissues were prepared for biochemical analysis. Total glutathione (tGSH) and malondialdehyde (MDA) levels of supernatants, which were obtained from the homogenates, were determined using appropriate methods based on the literature.

Preparation of samples: At this stage of the study, 0.2 -gram from each removed tissue was weighed. They were rounded up to $2 \mathrm{ml}$ in $1.15 \%$ potassium chloride solution for determining the MDA and in phosphate buffer with a $\mathrm{pH}$ of 7.5 for determining the $\mathrm{tGSH}$ and homogenized in an ice-cold medium. It was then centrifuged at $10000 \mathrm{rpm}$ at $+4^{\circ} \mathrm{C}$ for 15 minutes. The supernatant was used as an analysis sample.

Determination of MDA: It is based on spectrophotometric measurement at $532 \mathrm{~nm}$ wavelength of the 
absorbance of the pink colored complex formed by thiobarbituric acid (TBA) and MDA at a high temperature (at $95^{\circ} \mathrm{C}$ ) _ENREF_100 ${ }^{16}$. Homogenates were centrifuged at $5000 \mathrm{~g}$ for 20 minutes and these supernatants were used to identify the MDA amount. $250 \mu \mathrm{l}$ homogenate, $100 \mu \mathrm{l} 8 \%$ sodium dodecyl sulfate (SDS), $750 \mu \mathrm{l} 20 \%$ acetic acid, $750 \mu \mathrm{l} 0.08 \%$ TBA and $150 \mu \mathrm{l}$ distilled water were put into capped test tubes via pipetting and vortexed. The mixture was incubated at $100{ }^{\circ} \mathrm{C}$ for 60 minutes, and then, $2.5 \mathrm{ml}$ of n-butanol was added and measured spectrophotometrically. The red color intensity was read using $3 \mathrm{ml}$ cuvettes at 532 $\mathrm{nm}$ and MDA amount of samples was determined by a standard graph developed using an MDA stock solution prepared by considering the dilution coefficients.

Determination of tGSH: DTNB [5.5'-Dithiobis (2-nitrobenzoic acid)] in the measuring medium is a disulfide chromogen easily reduced by sulfhydryl compounds. Yellow color intensity was measured spectrophotometrically at $412 \mathrm{~nm}^{17}$. Homogenates were centrifuged for 10 minutes at $12000 \mathrm{~g}$ and supernatants were used to determine the GSH amount. 1500 $\mu \mathrm{l}$ measuring buffer $(200 \mathrm{mM}$ Tris- $\mathrm{HCl}$ containing $0.2 \mathrm{mM}$ EDTA, $\mathrm{pH}=8.2), 500 \mu \mathrm{l}$ supernatant, $100 \mu \mathrm{l}$ 5.5'-Dithio-bis (2-nitrobenzoic acid) (DTNB) and $7900 \mu \mathrm{l}$ of methanol were put into capped test tubes via pipetting and then vortexed. The mixture was incubated at $37^{\circ} \mathrm{C}$ for 30 minutes and measured spectrophotometrically. The amount of yellow form was read using $3 \mathrm{ml}$ quartz cuvettes at $412 \mathrm{~nm}$ and GSH amount of samples was determined by a standard graph developed using an GSH stock solution prepared by taking into consideration dilution coefficients.

Measurements of TOS and TAS: TOS and TAS levels of cochlear tissue homogenates were determined using a novel automated measurement method and commercially available kits (Rel Assay Diagnostics, Turkey), both developed by Erel ${ }^{18,19}$. The TAS method is based on the bleaching of characteristic color of a more stable ABTS (2.2'-azino-bis (3-ethylbenzothiazoline-6-sulfonic acid)) radical cation by antioxidants and, measurements is performed $660 \mathrm{~nm}$. The results are expressed as nmol hydrogen peroxide $\left(\mathrm{H}_{2} \mathrm{O}_{2}\right)$ equivalent/L. In TOS method, the oxidants present in the sample oxidized the ferrous ion-o-dianisidine complex to ferric ion. The oxidation reaction was enhanced by glycerol molecules, abundantly present in the reaction medium. The ferric ion produced a colored complex with xylenol orange in an acidic medium. The color intensity, which could be measured at $530 \mathrm{~nm}$ spectrophotometrically, was related to the total amount of oxidant molecules present in the sample. The results were expressed as $\mu \mathrm{mol}$ Trolox equivalent/L. The percentage ratio of TOS to TAS was used as the oxidative stress index (OSI). OSI was calculated as TOS divided by 100xTAS.

Histopathological examination: Following a routine tissue monitoring, sections of $5 \mu \mathrm{m}$ were obtained for histopathological examination. These sections were stained using Hematoxylin-Eosin ( $\mathrm{H} \& \mathrm{E})$ and cochlear tissues were evaluated using light microscopy (Olympus BX 51, Japan) by a pathologist uninformed of the treatment protocol, and the photographs were taken using a digital camera (Olympus DP71).

\section{Statistical Analyses}

Results obtained from the experiments were expressed as" mean value \pm standard error " $(x \pm$ SEM $)$. Level of significance of the difference among groups were determined using the one-way ANOVA test. After that, Fisher's post-hoc LSD (least significant differences) was conducted. All statistical procedures were carried out on "IBM SPSS Statistics Version 20" and p $<0.05$ was considered significant.

\section{Results}

\section{Biochemical Findings}

MDA and tGSH Analysis Results: As can be seen in Figure 1, the amount of MDA in cochlear tissues of animals administered amikacin increased significantly compared to healthy and taxifolin groups. However, the difference in MDA amount in healthy and taxifolin groups was statistically insignificant. The tGSH amount in amikacin group was found to be less compared to that of healthy and taxifolin groups. The difference in the amount of $\mathrm{tGSH}$ in the healthy group and the taxifolin group was found insignificant.

TOS and TAS analysis results: It was found that amikacin significantly increased the level of TOS in the cochlear tissue of animals compared to healthy and taxifolin groups. TOS levels were similar in healthy and taxifolin groups. Amikacin led to a decrease in TAS level in the cochlear tissue of animals. However, taxifolin significantly prevented the decrease of TAS level associated with amikacin and the difference in TAS level between the healthy and the taxifolin groups was found to be insignificant (Figure 2). 


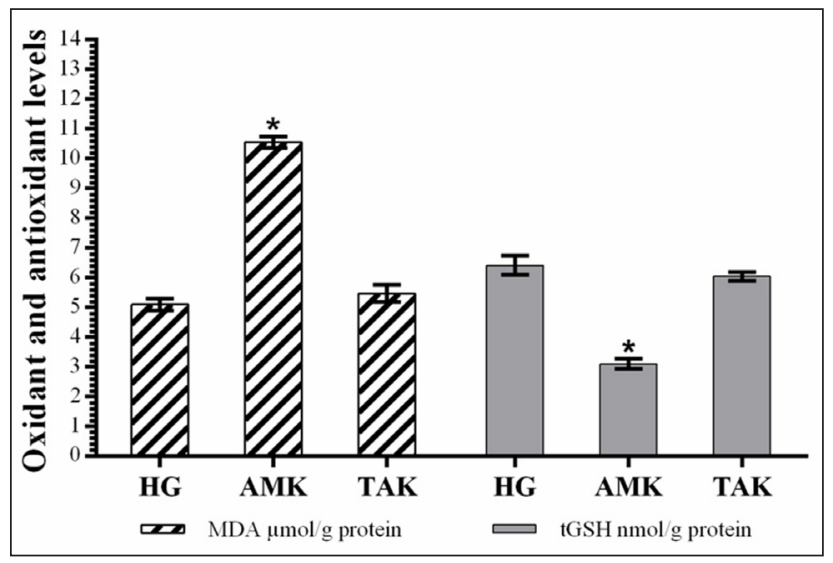

Figure 1. MDA and tGSH levels in the cochlea tissue of study groups. According to $H G$ and $T A K$ groups ${ }^{*}=p<0.0001,(n=6)$.

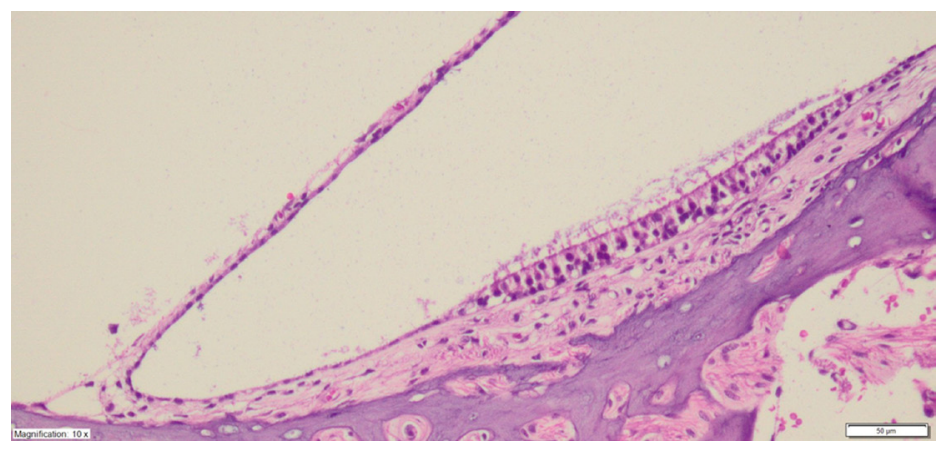

Figure 3. Cochlear tissue of the healthy animal group (HEx200).

\section{Histopathological Findings}

Figure 3 shows normal cochlear tissue of the healthy group. Severe edema and deconstruction can be seen in cochlea of the group only administered amikacin. Vestibular membrane degeneration was also detected in the amikacin group (Figure 4). In addition to edema in the cochlea, no other histopathological finding was observed in the animal group treated with taxifolin (Figure 5).

\section{Discussion}

Since any other alternatives have not been found for amikacin and other AGAs, ototoxicity caused by these drugs is still open to discussion. Even though there have been various experimental studies to prevent amikacin-induced ototoxicity, clinical studies are still conducted for new strategies on its prevention ${ }^{1}$. The present study investigated the protective effect of taxifolin on amikacin-induced ototoxicity in rats biochemically and histopathologically. Literature suggests that AGAs are both vestibulotoxic and cochleotoxic $^{8}$. In this group, streptomycin and gentamycin

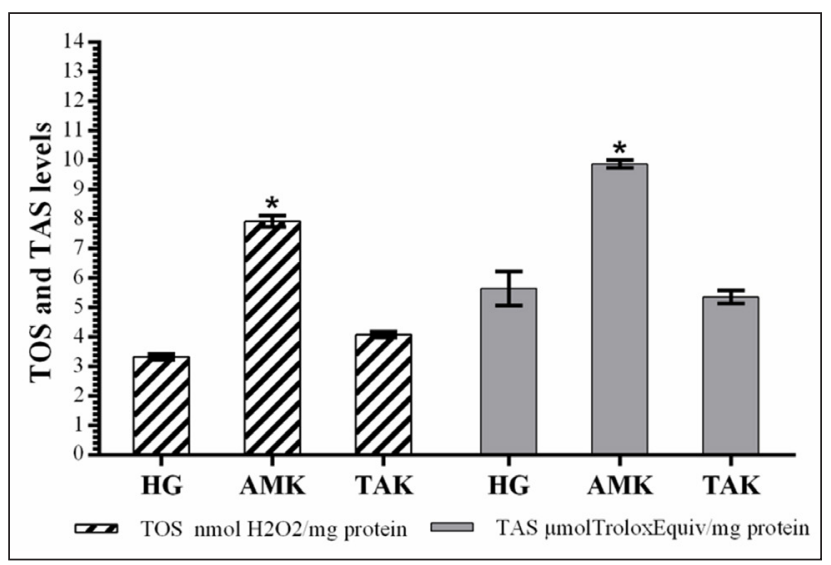

Figure 2. TOS and TAS levels in the cochlea tissue of study groups. According to $H G$ and TAK groups ${ }^{*}=p<0.0001,(n=6)$.

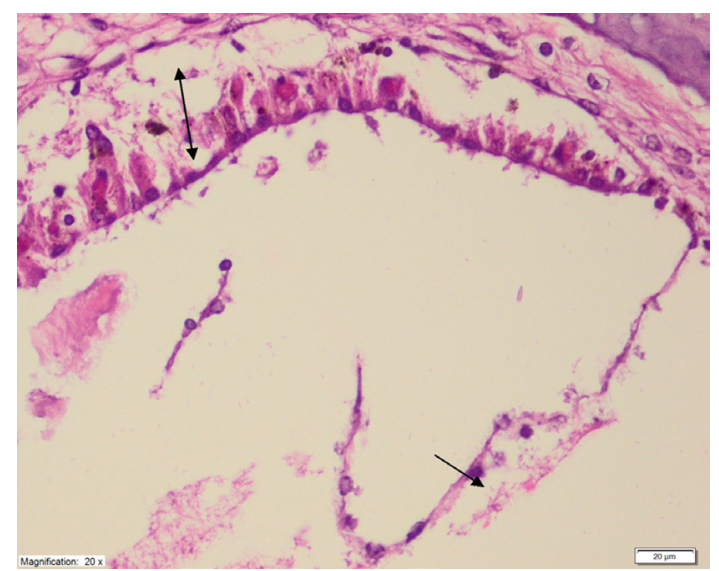

Figure 4. Animal group administered only amikacin: cochlear edema and deconstruction (double-headed arrow), vestibular membrane degeneration (single-headed arrow, HEx400).

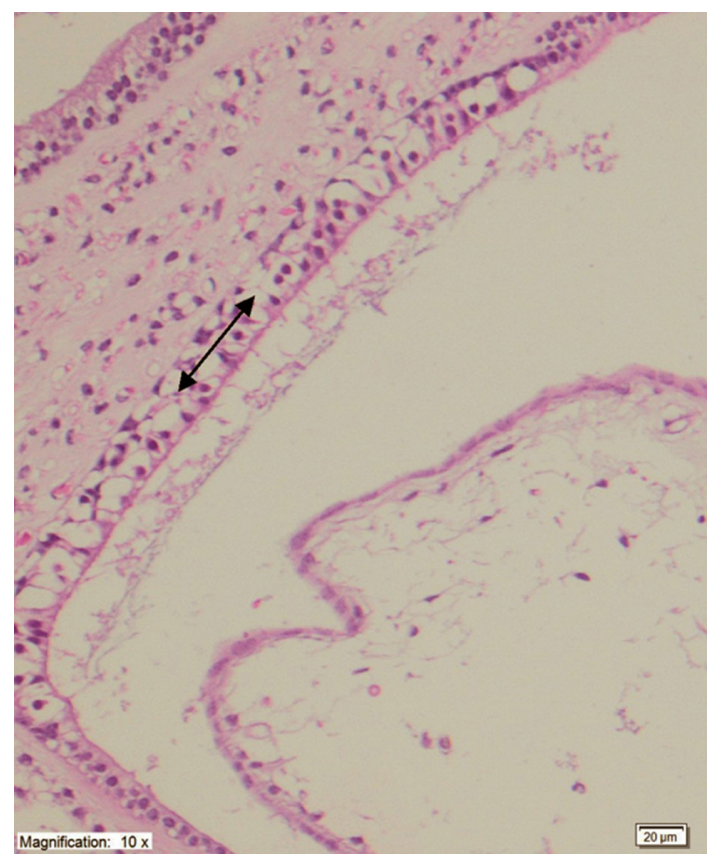

Figure 5. Animal group treated with taxifolin: Edema in cochlea (double-headed arrow, HEx200). 
were reported to be more vestibulotoxic, while other AGAs were reported to be cochelotoxic ${ }^{1}$. As mentioned above, over-production of ROS is responsible for the pathogenesis of amikacin ototoxicity ${ }^{7,8}$. The results of the biochemical experiments performed under this study show that MDA and TOS levels in the cochlear tissues of animals administered amikacin significantly increased, while tGSH and TAS levels decreased compared to healthy and taxifolin groups. A correlation was reported between increased MDA levels associated with amikacin in the cochlea and auditory dysfunction ${ }^{20}$. Aksoy $\mathrm{F}$ et al. reported that the increase in total oxidant level (TOS) due to amikacin led to sensorineural hearing loss in rats ${ }^{9}$. In our study, tGSH level in the amikacin group was found to be lower compared to healthy and taxifolin groups. In addition to low tGSH, TAS level was also low in the amikacin group. These results suggest that the physiological balance between the oxidant and the antioxidant is disrupted in the amikacin group. Literature reveals that the disruption of this balance leads to tissue damage, which is called oxidative stress ${ }^{21}$. It has been reported that a decrease in the amount of antioxidants in the cochlear tissue may result in auditory dysfunction ${ }^{20}$. It has also been reported that low TAS caused hearing loss in rats 9 .

In our study, we used high MDA and low tGSH levels as a base for evaluating the oxidative damage to cochlear tissue. MDA is a reliable end product of lipid peroxidation (LPO) ${ }^{22}$. This is the reason why MDA is widely used as an indicator of oxidative status ${ }^{23}$. Increased MDA level indicates increased ROS. The MDA formed as a result of LPO is toxic and may cause further destruction ${ }^{24}$. However, in healthy tissues, the harmful effects of these oxidants are prevented by GSH and other enzymatic and non-enzymatic antioxidants. GSH is an antioxidant tripeptide composed of L-glutamate, L-cysteine, and glycine found in cells. GSH reacts with hydrogen peroxide $\left(\mathrm{H}_{2} \mathrm{O}_{2}\right)$ and organic peroxides to detoxify and protect cells from $\mathrm{SOR}$ damage $)^{25}$.

The cochlear structure (architecture) was examined histopathologically to prove the accuracy of the results of our biochemical experiment. While edema and destruction were observed in the cochlear tissue of the group only administered amikacin, degeneration was identified in the vestibular membrane. In a study, which was conducted long ago by Lenoir $\mathrm{M}$ et al. amikacin was shown to result in morphological changes in the cochlea ${ }^{26}$. Cazals et al. reported that amikacin caused destruction of the cochlea ${ }^{27}$. No destruction was observed on the cochlear tissue of the taxifolin group. In addition, degeneration was found in the vestibular membrane. Our histopathological findings are consistent with biochemical findings. There is no information in the literature about the protective effect of taxifolin on the cochlea. However, there are studies showing that taxifolin has a cytoprotective effect and protects tissues from oxidative damage ${ }^{13,28,29}$. Taxifolin has been reported to prevent bone loss due to osteoporosis by inhibiting ROS and proinflammatory cytokine overproduction ${ }^{30}$. In conclusion: Amikacin caused oxidative cochlear damage in animals. The cochleotoxic effect of amikacin has been demonstrated by biochemical and histopathological findings. It has been understood that taxifolin prevents amikacin-associated oxidative cochlear damage. This suggests that taxifolin may be beneficial in treating amikacin-associated ototoxicity.

\section{Conflict of Interest}

No potential conflict of interest was reported by the author (s).

\section{References}

1. Selimoglu E. Aminoglycoside-induced ototoxicity. Curr Pharm Des 2007;13(1):119-26.

2. Hutchin T, Cortopassi G. Proposed molecular and cellular mechanism for aminoglycoside ototoxicity. Antimicrob Agents Chemother 1994;38(11):2517-20.

3. Begg EJ, Barclay ML. Aminoglycosides: 50 years on. Br J Clin Pharmacol 1995 6;39(6):597-603.

4. Aksoy F, Dogan R, Ozturan O, Tugrul S, Veyseller B, Ozer OF, et al. An evaluation of the protective effects of thymoquinone on amikacin-induced ototoxicity in rats. Clin Exp Otorhinolaryngol 2015;8(4):312-19.

5. Murillo-Cuesta S, Contreras J, Cediel R, Varela-Nieto I. Comparison of different aminoglycoside antibiotic treatments to refine ototoxicity studies in adult mice. Lab Anim 2014;44(2):124-31.

6. World Health OrganizationReport of an Informal Consultation on Strategies for Prevention of Hearing Impairment from Ototoxic Drugs, vol 95, WHO/PDH(1994), p.2.

7. Huth ME, Ricci AJ, Cheng AG. Mechanisms of aminoglycoside ototoxicity and targets of hair cell protection. Int J Otolaryngol 2011;2011:937861.

8. Rizzi MD, Hirose K. Aminoglycoside ototoxicity. Curr Opin Otolaryngol Head Neck Surg 2007;15(5):352-57.

9. Aksoy F, Dogan R, Ozturan O, Eren SB, Veyseller B, Pektas $A$, et al. Protective effect of trimetazidine on amikacininduced ototoxicity in rats. Int $\mathrm{J}$ Pediatr Otorhinolaryngol 2014;78(4):663-69. 
10. Rice-Evans CA, Miller NJ, Paganga G. Structure-antioxidant activity relationships of flavonoids and phenolic acids. Free Radic Biol Med 1996;20(7):933-56.

11. Cotelle N. Role of flavonoids in oxidative stress. Curr Top Med Chem 2001;1(6):569-90.

12. Ahiskali I, Pinar CL, Kiki M, Cankaya M, Kunak CS, Altuner D. Effect of taxifolin on methanol-induced oxidative and inflammatory optic nerve damage in rats. Cutan Ocul Toxicol 2019;12:1-6.

13. Eken H, Cimen O, Cimen FK, Kurnaz E, Yildirim M, Tasova $\mathrm{V}$, et al. Effect of taxifolin on oxidative gastric injury induced by celiac artery ligation in rats. Acta Cir Bras 2019;34(4): e201900404.

14. Unver E, Tosun M, Olmez H, Kuzucu M, Cimen FK, Suleyman Z. The effect of taxifolin on cisplatin-induced pulmonary damage in rats: a biochemical and histopathological evaluation. Mediators Inflamm 2019;12:3740867.

15. Topal F, Nar M, Gocer H, Kalin P, Kocyigit UM, Gülçin İ, et al. Antioxidant activity of taxifolin: an activity-structure relationship. J Enzyme Inhib Med Chem 2016;31(4):674-83.

16. Ohkawa H, Ohishi N, Yagi K. Assay for lipid peroxides in animal tissues by thiobarbituric acid reaction. Anal Biochem 1979;95(2):351-8.

17. Sedlak J, Lindsay RH. Estimation of total, protein-bound, and nonprotein sulfhydryl groups in tissue with Ellman's reagent. Anal Biochem 1968;25(1):192-205.

18. Erel O. A novel automated method to measure total antioxidant response against potent free radical reactions. Clin Biochem 2004;37:112-9.

19. Erel O. A new automated colorimetric method for measuring total oxidant status. Clin Biochem 2005;38:1103-11.

20. Klemens JJ, Meech RP, Hughes LF, Somani S, Campbell K. Antioxidant enzyme levels inversely covary with hearing loss after amikacin treatment. J Am Acad Audiol 2003;14(3):134-43.
21. Kisaoglu A, Borekci B, Yapca OE, Bilen H, Suleyman H. Tissue damage and oxidant/antioxidant balance. Eurasian J Med 2013;45(1):47-9.

22. Del Rio D, Stewart AJ, Pellegrini N. A review of recent stud $\neg$ ies on malondialdehyde as toxic molecule and biological marker of oxidative stress. Nutr Metab Cardiovasc Dis 2005; 15:316-28.

23. Draper $\mathrm{H}$, Hadley M. Malondialdehyde determination as in $\neg$ dex of lipit peroxidation. Methods Enzymol 1990;186:42131.

24. Slater TF. Free-radical mechanisms in tissue injury. Biochem J 1984;222:1-15.

25. Murray RK, Granner DK, Mayes PA, VM. R. Harper's Biochemistry 25. Baskı. USA, McGraw-Hill Press, 2000.

26. Lenoir M, Daudet N, Humbert G, Renard N, Gallego M, Pujol R, et al. Morphological and Molecular Changes in the Inner Hair Cell Region of the Rat Cochlea After Amikacin Treatment. J Neurocytol 1999;28(10-11):925-37.

27. Cazals Y, Aran JM, Erre JP, Guilhaume A. Acoustic responses after total destruction of the cochlear receptor: brainstem and auditory cortex. Science 1980;210(4465):83-6.

28. Tang Z, Yang C, Zuo B, Zhang Y, Wu G, Wang Y, et al. Taxifolin protects rat against myocardial ischemia/reperfusion injury by modulating the mitochondrial apoptosis pathway. Peer J 2019;31(7): e6383.

29. Ye Y, Wang X, Cai Q, Zhuang J, Tan X, He W, et al. Protective Effect of Taxifolin on H2O2-induced H9C2 Cell Pyroptosis. Zhong Nan Da Xue Xue Bao Yi Xue Ban 2017;42(12):136774.

30. Cai C, Liu C, Zhao L, Liu H, Li W, Guan H, et al. Effects of taxifolin on osteoclastogenesis in vitro and in vivo. Front Pharmacol 2018;12(9):1286. 